\title{
Community Work
}

Alan Twelvetrees

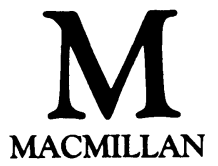


(๑) British Association of Social Workers 1982

All rights reserved. No reproduction, copy or transmission of this publication may be made without written permission.

No paragraph of this publication may be reproduced, copied or transmitted save with written permission or in accordance with the provisions of the Copyright Act 1956 (as amended).

Any person who does any unauthorised act in relation to this publication may be liable to criminal prosecution and civil claims for damages.

First published 1982

Reprinted 1985

Published by

Higher and Further Education Division

MACMILLAN PUBLISHERS LTD

Houndmills, Basingstoke, Hampshire RG21 2XS

and London

Companies and representatives

throughout the world

ISBN 978-0-333-30900-1 ISBN 978-1-349-16699-2 (eBook)

DOI 10.1007/978-1-349-16699-2 


\section{Contents}

Acknowledgements

viii

Introduction 1

1 What is Community Work? 4

Theoretical perspectives 4

A rationale for employing community workers $\quad 12$

$\begin{array}{ll}\text { Types of community groups } & 13\end{array}$

The dual objectives of community work $\quad 15$

Types of community work 16

$\begin{array}{ll}\text { Conclusion } & 18\end{array}$

2 Contact-making, Analysis and Planning 20

Introduction $\quad 20$

Before starting the job 21

Contact-making - your bread and butter 22

A community profile $\quad 28$

Purpose of a community profile 28

Gathering information in your own agency $\quad 29$

Gathering hard information $\quad 31$

Gathering information from residents 33

Analysis, planning and organisation 36

3 Work with Community Groups:

I - Practical Considerations $\quad 39$

Intensive work to set up a group $\quad 39$

$\begin{array}{ll}\text { Bringing people together } & 40\end{array}$ 
Expanding the membership $\quad 42$

Focusing on one objective 43

Organisational and interactional skills $\quad 45$

The worker's role in meetings $\quad 47$

Work with individual group members $\quad 48$

Structuring the group $\quad 50$

The need for hard resources $\quad 52$

Creating a constituency 53

Relationships with the outside world $\quad 56$

Professionals in groups $\quad 57$

Work with existing groups $\quad 58$

Reviving moribund groups $\quad 58$

A directive approach to setting up a group $\quad 59$

Work with larger organisations $\quad 61$

Withdrawal $\quad 64$

Using the media $\quad 69$

$\begin{array}{ll}\text { Money } & 70\end{array}$

Relationships with politicians $\quad 70$

$\begin{array}{ll}\text { Living in the area } & 72\end{array}$

The paradox of buildings $\quad 73$

Advice centres $\quad 73$

4 Work with Community Groups:

II - Psychological Considerations $\quad 75$

Participation in voluntary action $\quad 75$

Factors preventing people joining groups $\quad 75$

Why do people participate? $\quad 76$

How far do the poor participate? 78

Understanding and influencing group processes $\quad 78$

$\begin{array}{ll}\text { The effects of work with community groups } & 88\end{array}$

5 Working towards Institutional Change 92

Campaigning from outside the system 92

Working the system $\quad 95$

Work with other parties to benefit existing
groups

Initiating and managing projects $\quad 98$

Inter-agency work $\quad 105$ 
Changing your agency - the case of community social work

6 Survival

Surviving agency pressure

Preserving your job

The stresses of the job

The need for supervision

122

Conscious practice

124

The importance of recording

125

Evaluation

127

Conclusion

128

References and Further Reading

Index 


\section{Acknowledgements}

I am grateful to Raymond Pringle and John Wright for their comments on the first draft of this book, and to Iris John for typing the manuscript. I am, in addition, indebted to the tenants of the housing estate on which I worked, some of whom appear here under different names. I would also like to thank the many other community workers, students and other professionals whose ideas I have sometimes consciously and often, I am sure, unconsciously used. Finally, I would like to thank my wife both for her helpful comments on the first draft and for her constant encouragement.

University College of Swansea

Alan Twelvetrees 
To Jennifer, Clare and Oliver 